\title{
IQTISHODUNA
}

IQTISHODUNA: Jurnal Ekonomi Islam

E-ISSN: 2443-0056, P-ISSN: 2252-5661

Accredited Number 21/E/KPT/2018

Volume 9 Issue 1, April 2020 | Page: 55-74

DOI: doi.org/10.36835/iqtishoduna.v9i1.470

\section{Development Strategy for Micro, Small, and Medium Enterprises through Islamic Financial Inclusion}

\author{
Novatul Isrowiyah', Warno ${ }^{2}$, Rahman El Junusi ${ }^{3}$ \\ 1,2,3 Departement of Islamic Banking, Faculty of Islamic Economics and Business, Universitas \\ Islam Negeri Walisongo Semarang, Jl. Walisongo No.3-5 Tambakaji Kec. Ngaliyan Kota \\ Semarang Jawa Tengah 50185, Indonesia \\ e-mail: ${ }^{1}$ novaisrowy@gmail.com ${ }^{2}$ warno@walisongo.ac.id ${ }^{3}$ rahman_junusi@walisongo.ac.id
}

\begin{abstract}
This study calculates and analyzes the Islamic financial inclusion index which covers three dimensions; accessibility, availability, and usage of sharia banking. The results showed that the level of Islamic financial inclusion in Indonesia was classified as low during the study period and DKI Jakarta Province was the most inclusive province in Indonesia. Furthermore, this study analyzes the effect of the Islamic financial inclusion index on Islamic financing channeled to Micro, Small and Medium Enterprises (MSMEs) in Indonesia. Using the saturated sampling method, a total of 33 provinces in Indonesia were selected as samples with an observation period. The results show that the Islamic Financial Inclusion Index (IIK) has a significant positive effect on sharia financing channeled to the MSME sector, one of the regions that appears to be growing faster than other regions is Aceh. This research is different from previous financial sector inclusiveness studies that still see and study conventional (non-sharia) financial inclusion and find out the impact of sharia financial inclusion based on sharia financial inclusion indexes on sharia financing distributed to Micro, Small and Medium Enterprises in Indonesia and discuss comprehensively for MSME.
\end{abstract}

Keywords: Islamic Financial Inclusion, Islamic Banking, MSME Islamic Financial

Abstrak: Penelitian ini menghitung dan menganalisis indeks inklusi keuangan syariah yang mencakup tiga dimensi; aksesibilitas, availabilitas, dan usage perbankan syariah. Hasil penelitian menunjukkan bahwa tingkat inklusi keuangan syariah di Indonesia tergolong rendah selama periode penelitian dan Provinsi DKI Jakarta adalah provinsi yang paling inklusif di Indonesia. Selanjutnya, penelitian ini menganalisis pengaruh indeks inklusi keuangan syariah terhadap pembiayaan syariah yang disalurkan pada Usaha Mikro Kecil dan Menengah (UMKM) di Indonesia. Menggunakan metode sampling jenuh, total 33 provinsi di Indonesia dipilih sebagai sampel dengan periode observasi. Hasilnya menunjukkan bahwa Indeks Inklusi Keuangan (IIK) Syariah berpengaruh positifsignifikan terhadap pembiayaan syariah yang disalurkan pada sektor UMKM, salah satu daerah yang terlihat berkembang lebih pesat dibandingkan daerah lain adalah Aceh. Penelitian ini menjadi berbeda dari penelitian-penelitian inklusifitas sektor keuangan sebelumnya yang masih melihat dan mengkaji inklusifitas keuangan konvensional (non-syariah) serta mengetahui dampak inklusi keuangan syariah berdasarkan indeks inklusi keuangan syariah terhadap pembiayaan syariah yang disalurkan pada Usaha Mikro, Kecil dan Menengah di Indonesia serta membahas secara komprehensif untuk UMKM.

Kata kunci: Inklusi Keuangan syariah, perbankan syariah, pembiayaan syariah UMKM.

\section{Introduction}

Access to formal financial services is an important factor that supports poverty alleviation efforts. ${ }^{1}$ The formal financial sector, especially

${ }^{1}$ Laura Grace Gabriella dan Miranda Swaray Goeltom, Pengaruh pembangunan 
56 IQTISHODUNA: Jurnal Ekonomi Islam Volume 9 Issue1, April 2020

banking, plays an important role in providing access to the public to utilize financial services because banking is the financial sector that controls the financial industry in Indonesia. OJK Statistics noted that banks have the largest assets compared to other financial institutions, reaching $\mathrm{Rp} 8,068$ trillion in December 2018 or around $78 \%$ percent of total financial industry assets in 2018. Based on the National Literacy and OJK Financial Inclusion Survey, Banking is the main financial service provider in Indonesia because it has the highest sectoral financial inclusion index after BPJS Health in 2016 which amounted to $63.63 \%$.

Graph 1.1Percentage of adult population (aged 15 years and over) who have access to financial institutions in several ASEAN countries

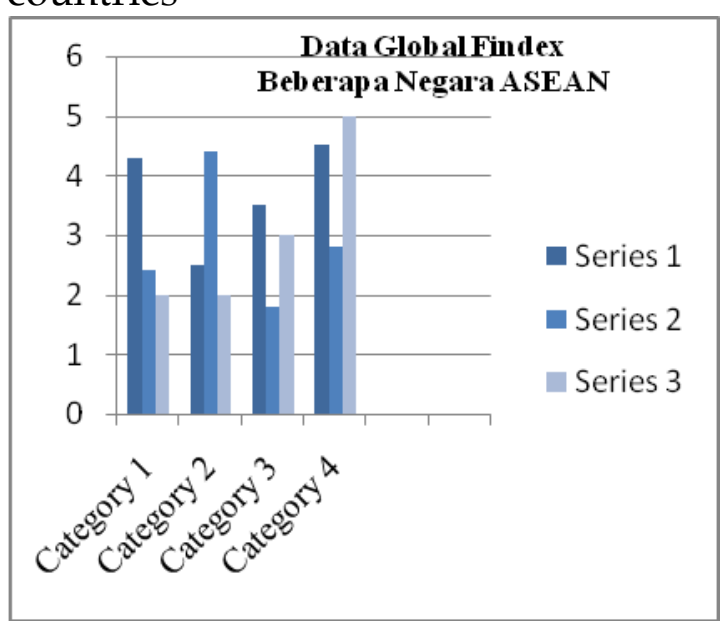

Source: Findex Global

Database, World Bank

Keuangan Perbankan dan Akses Keuangan Perbankan Terhadap Kemiskinan di Indonesia, FE Universitas Indonesia, 2013
Strategies for increasing financial inclusion include the Savings Indonesia Movement (GIM) program, My Savings, Digital Financial Services, Financial Identity Number (FIN), Information Systems for Farmers \& Fishermen (SIPN), Smart Practice or Branchless Banking, People's Business Credit (KUR), E-Money, Telkomsel Cash, and microfinance service improvements. In the National Inclusive Financial Strategy (SNKI) there are six pillars namely financial education, public financial facilities, financial information mapping, supporting policies / regulations, intermediation and distribution facilities, consumer protection. The target of this policy is very concerned about the poor lowincome, productive poor, migrant workers, and people living in remote areas. $^{2}$

Inclusive finance is closely related to the Micro, Small and Medium Enterprises (MSME) sector. MSME has an important role in inclusive finance because it is the majority economy of the people. Based on data from the Ministry of Cooperatives and Small and Medium Enterprises of the Republic of Indonesia in 2017, the MSME sector has a proportion of approximately 99 percent more than the total number of Indonesian business people or as many as 62.92 million business units and is capable

\footnotetext{
Inklusif,

https://www.bi.go.id/id/perbankan/keua nganinklusif/program/Contents/default.as px accessed February 13, 2019
}

${ }^{2}$ Bank Indonesia, Program Keuangan 

through Islamic Financial Inclusion

of absorbing more than 116 million people. MSMEs have a workforce absorption rate of around $97 \%$ of the entire national workforce. The contribution of MSMEs to the National Gross Domestic Product (GDP) is greater than that of large businesses, namely GDP according to current prices in 2017 at $60 \%$, while GDP based on constant prices is $57.08 \%$.

Graph 1.2The Proportion of MSMEs and Large Enterprises in 2017

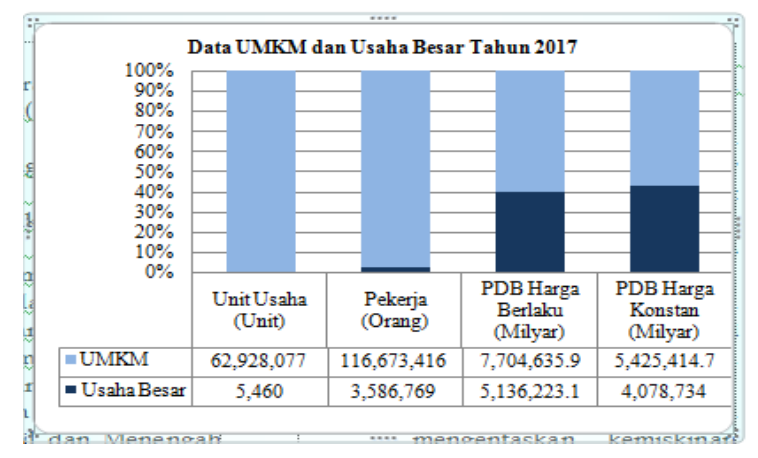

Source: depkop.go.id, processed 2019

Based on these data, the MSME sector has a large contribution to the country's economy. Efforts to advance and develop the MSME sector will be able to absorb more available workforce so that it can improve the welfare of the workers involved in it and reduce unemployment which will ultimately reduce poverty. ${ }^{3}$

Although MSMEs occupy a fairly central economic foundation as

3Supriyanto, Pemberdayaan Usaha Mikro, Kecil, dan Menengah (UMKM) Sebagai Salah Satu Upaya Penanggulangan Kemiskinan, Jurnal Ekonomi \& Pendidikan, Volume 3 Nomor 1, April 2006, h. 1-16 the majority of businesses, MSMEs have limited access to capital, especially financing or credit from bank financial institutions. MSME access to capital is still not optimal. MSMEs are difficult to access capital from formal financial institutions because their business background can be categorized as unbankable or also called a deficit business group. ${ }^{4}$ Based on Bank Indonesia data, financing or credit channeled to MSMEs at the end of 2018 only reached $19.85 \%$ percent or about one fifth of the national credit share. Thus, an inclusive financial system could be a solution for micro businesses that cannot access to obtain financing from banking institutions in order to develop their business.

Inclusive finance has multidimensional indicators, Sarma (2012) argues that there are three dimensions that can be used to represent multidimensional financial inclusion, namely accessibility, availability and utilization of banking services. ${ }^{5}$ Bank Indonesia also revealed the dominant factors in inclusive finance, namely the

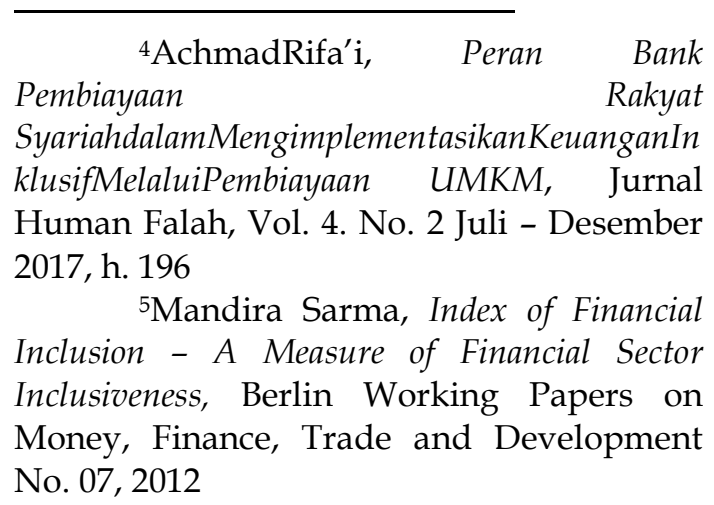


58 IQTISHODUNA: Jurnal Ekonomi Islam Volume 9 Issue1, April 2020

dimensions of access, use, and quality of banking services. ${ }^{6}$

One indicator used to measure the extent to which inclusive financial services have been carried out by a country is through measurement of the financial inclusion index.7In addition, the measurement of the level of financial inclusion based on the financial inclusion index can also be used to determine the distribution of banking sector services. ${ }^{8}$ Considering the role of financial sector inclusiveness is very important for economic growth, the measurement of Islamic financial inclusiveness in Indonesia can be one of the efforts to increase Islamic financial inclusion by providing input for the government and related parties in designing inclusive economic and financial policies based on evidence and empirical findings.

Based on the background that has been stated, this study measures and analyzes the inclusiveness of the Islamic financial sector in 33 provinces in Indonesia by using

${ }^{6}$ Bank Indonesia, Strategi Nasional Keuangan Inklusif,

https://www.bi.go.id/id/perbankan/keua nganinklusif/Indonesia/strategi/Contents/

Default.aspxaccessed January 28, 2019

${ }^{7}$ Mandira Sarma, Index of Financial Inclusion - A Measure of Financial Sector Inclusiveness, Berlin Working Papers on Money, Finance, Trade and Development No. 07, 2012

8BintanBadriatulUmmah,

etal.,AnalisisInklusiKeuangandanPemerataanPe ndapatan di Indonesia, JurnalEkonomidanKebijakanPembanguan,Vol 4 No. 1, h. 3
Islamic banking data and measures the influence of the Islamic financial inclusion index on sharia financing channeled to the Micro, Small and Medium Enterprises (MSME) sector in 33 provinces in Indonesia. This study connects financial inclusion with Islamic financing at MSME based on the results of Fahmy et al. which states that financial inclusion as measured by the dimensions of access and use has a positive and partially significant effect on credit extended to the micro, small and medium business sector, and together with the LDR control variable with the access variable and the use of banking service variables have a significant positive effect on distribution of MSME loans in Indonesia. ${ }^{9}$

This research is different from previous financial sector inclusiveness studies which still see and study the conventional (nonsharia) financial inclusiveness. The author conducted this research to determine the Islamic financial inclusion index in Indonesia and to know the impact of Islamic financial inclusion based on the Islamic financial inclusion index on Islamic financing channeled to Micro, Small and Medium Enterprises in Indonesia and discuss comprehensively to increase inclusion and MSMEs.

\footnotetext{
9Obaid M Fahmy, et al., PengaruhKeuanganInklusifterhadapkredit yang disalurkanpadasektor Usaha Mikro, Kecil danMenengah (UMKM) di Indonesia. JurnalEkonomiBisnisdanKewirausahaan, Vol . 5, No. 2, 2016, h. 118 - 135
} 
Novatul Isrowiyah, Warno, Rahman El Junusi:

Development Strategy for Micro, Small and Medium Enterprises

\section{Research Methods}

\subsection{Data Types and Sources}

This study uses secondary data from sharia banking which includes Sharia Commercial Banks, Sharia Business Units and Sharia Rural Banks based on annual 2013-2018 in 33 provinces in Indonesia sourced from the Sharia Banking Statistics (SPS) Financial Services Authority and the Central Statistics Agency ( BPS). The data collected is as below:

\begin{tabular}{c|l|c}
\hline No. & \multicolumn{1}{|c}{ Data } & Source \\
\hline 1 & $\begin{array}{l}\text { Adult population (15+) } \\
\text { per province in 2015-2018 }\end{array}$ & BPS \\
\hline 2 & $\begin{array}{l}\text { Number of sharia bank } \\
\text { offices (BUS and UUS) } \\
\text { per province in 2015-2018 }\end{array}$ & SPS \\
\hline 3 & $\begin{array}{l}\text { Total Sharia Banking } \\
\text { Third Party Funds (DPK) } \\
\text { per Province in 2015-2018 }\end{array}$ & SPS \\
\hline 4 & $\begin{array}{l}\text { The amount of financing } \\
\text { disbursed by Islamic } \\
\text { banking per province in } \\
\text { 2015-2018 }\end{array}$ & SPS \\
\hline 5 & $\begin{array}{l}\text { Number of GRDP per } \\
\text { province in 2015-2018 }\end{array}$ & BPS \\
\hline 6 & $\begin{array}{l}\text { The amount of sharia } \\
\text { financing distributed to } \\
\text { the MSME sector per } \\
\text { province in 2015-2018 }\end{array}$ & SPS \\
\hline
\end{tabular}

\subsection{Research Variable}

This study uses the financial inclusion index method or Index of Financial Inclusion (IFI) developed by Sarma (2012) in analyzing and measuring Islamic financial inclusion in Indonesia, so the research variables used refer to the dimensions of measuring the financial inclusion index namely accessibility, availability, and usage. The through Islamic Financial Inclusion

operational definition of these variables is as follows:

\begin{tabular}{|c|c|c|c|c|}
\hline $\begin{array}{l}\mathbf{N} \\
\mathbf{o}\end{array}$ & $\begin{array}{l}\text { Dime } \\
\text { nsion }\end{array}$ & $\begin{array}{l}\text { Defin } \\
\text { ition }\end{array}$ & $\begin{array}{c}\text { Indica } \\
\text { tor }\end{array}$ & Measurement \\
\hline I. & \multicolumn{4}{|c|}{$\begin{array}{l}\text { Analysis of Measurement of Islamic Financial } \\
\text { Inclusion Index }\end{array}$} \\
\hline \multicolumn{2}{|c|}{$\begin{array}{l}\text { Accsessibili } \\
\quad \text { ty }\end{array}$} & $\begin{array}{l}\text { Meas } \\
\text { uring } \\
\text { the } \\
\text { penetr } \\
\text { ation } \\
\text { of } \\
\text { Islami } \\
\text { c } \\
\text { banks } \\
\text { in the } \\
\text { comm } \\
\text { unity } \\
\text { (Sarm } \\
\text { a, } \\
\text { 2012) }\end{array}$ & $\begin{array}{l}\text { The } \\
\text { ratio } \\
\text { of the } \\
\text { numb } \\
\text { er of } \\
\text { Islami } \\
\text { c bank } \\
\text { third } \\
\text { party } \\
\text { funds } \\
\text { per } \\
1,000 \\
\text { poor } \\
\text { adults }\end{array}$ & $\begin{array}{l}\text { Total DPK } \\
\text { IslamicBanking } \\
\text { Number of Adults } \\
\text { Numbo }\end{array}$ \\
\hline \multicolumn{2}{|c|}{$\begin{array}{l}\text { Availabilit } \\
y\end{array}$} & $\begin{array}{l}\text { Meas } \\
\text { uring } \\
\text { the } \\
\text { ability } \\
\text { to use } \\
\text { Islami } \\
\text { c } \\
\text { banki } \\
\text { ng } \\
\text { servic } \\
\text { es by } \\
\text { the } \\
\text { public } \\
\text { (Sarm } \\
\text { a, } \\
\text { 2012). }\end{array}$ & $\begin{array}{l}\text { The } \\
\text { ratio } \\
\text { of the } \\
\text { numb } \\
\text { er of } \\
\text { Islami } \\
\text { c bank } \\
\text { servic } \\
\text { e } \\
\text { offices } \\
\text { per } \\
100,00 \\
0 \\
\text { adult } \\
\text { popul } \\
\text { ation }\end{array}$ & $\begin{array}{l}\text { Total Office } \\
\frac{\text { Islamic Bamking }}{\text { Number of Adults }} \text { x 100,000 }\end{array}$ \\
\hline \multicolumn{2}{|c|}{ Usage } & $\begin{array}{l}\text { Meas } \\
\text { uring } \\
\text { the } \\
\text { extent } \\
\text { of the } \\
\text { use of } \\
\text { Islami } \\
\text { c } \\
\text { banki } \\
\text { ng } \\
\text { financ } \\
\text { ial } \\
\text { servic } \\
\text { es in } \\
\text { meeti } \\
\text { ng the } \\
\text { needs } \\
\text { of the } \\
\text { comm } \\
\text { unity, } \\
\text { (Sarm } \\
\text { a, } \\
\text { 2012). }\end{array}$ & $\begin{array}{l}\text { Islami } \\
\text { c bank } \\
\text { financ } \\
\text { ing for } \\
\text { Gross } \\
\text { Regio } \\
\text { nal } \\
\text { Dome } \\
\text { stic } \\
\text { Produ } \\
\text { ct } \\
\text { (GRD } \\
\text { P) }\end{array}$ & $\begin{array}{l}\text { Amount of Funding } \\
\frac{\text { IslamicBanking }}{\text { GRDP }} \times 1000\end{array}$ \\
\hline \multirow[t]{2}{*}{ II. } & \multicolumn{4}{|c|}{$\begin{array}{l}\text { Analysis of the Effect of Sharia Financial Inclusion on } \\
\text { Sharia Financing in the MSME sector }\end{array}$} \\
\hline & \multicolumn{2}{|c|}{ Variable } & \multicolumn{2}{|r|}{ Measurement } \\
\hline 1. & $\begin{array}{l}\text { Islamic } \\
\text { Financi } \\
\text { Inclusi } \\
(X)\end{array}$ & Index & $\begin{array}{l}\text { The val } \\
\text { inclusio } \\
\text { calculat }\end{array}$ & $\begin{array}{l}\text { of Islamic financial } \\
\text { index uses the Sarma } \\
\text { n method (2012) }\end{array}$ \\
\hline
\end{tabular}


IQTISHODUNA: Jurnal Ekonomi Islam Volume 9 Issue1, April 2020

\begin{tabular}{c|l|l}
\hline 2. & $\begin{array}{l}\text { Sharia } \\
\text { Financing at } \\
\text { MSME }(\mathrm{Y})\end{array}$ & $\begin{array}{l}\text { Total Sharia financing for BUS, UUS } \\
\text { and SRB distributed in the Micro, } \\
\text { Small and Medium Enterprises } \\
\text { sector }\end{array}$ \\
\hline
\end{tabular}

Source: Sarma (2012), Umar (2016)

Framework

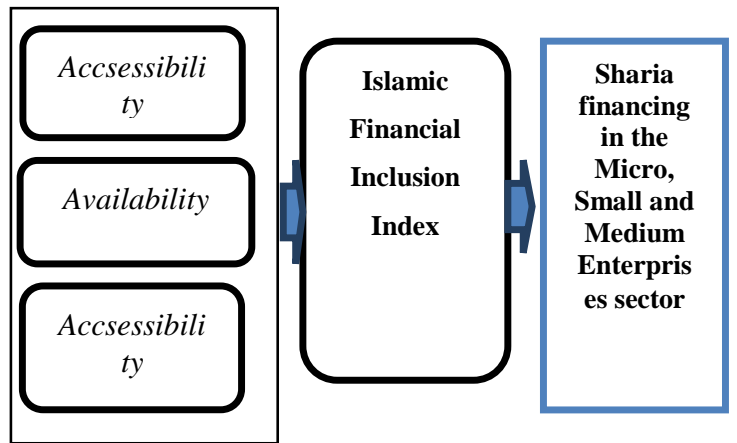

\section{Results and Discussion}

3.1 Islamic Financial Inclusion

\subsubsection{Dimensions of Islamic Financial Inclusion}

Financial inclusion is formed by 3 dimensions, namely banking penetration (accessibility), availability of banking services (availability), and use of banking services (usage). ${ }^{10}$ hese three dimensions are measured based on sharia banking data on 33 provinces in Indonesia in 2015-2018. This dimension is the ratio value of each indicator for each dimension. With limited data, the value of the dimensions forming sharia financial inclusion for each province in Indonesia in 2015-2018 can be seen in table 3.1. The results show several indicators such as: minimum (min), maximum (max), average (ave.), And standard deviation (stdev).

${ }^{10}$ Mandira Sarma, Index of Financial Inclusion - A Measure of Financial Sector Inclusiveness, Berlin Working Papers on Money, Finance, Trade and Development No. 07,2012
Table 3.1 Descriptive Statistics of Islamic Financial Inclusion Dimensions

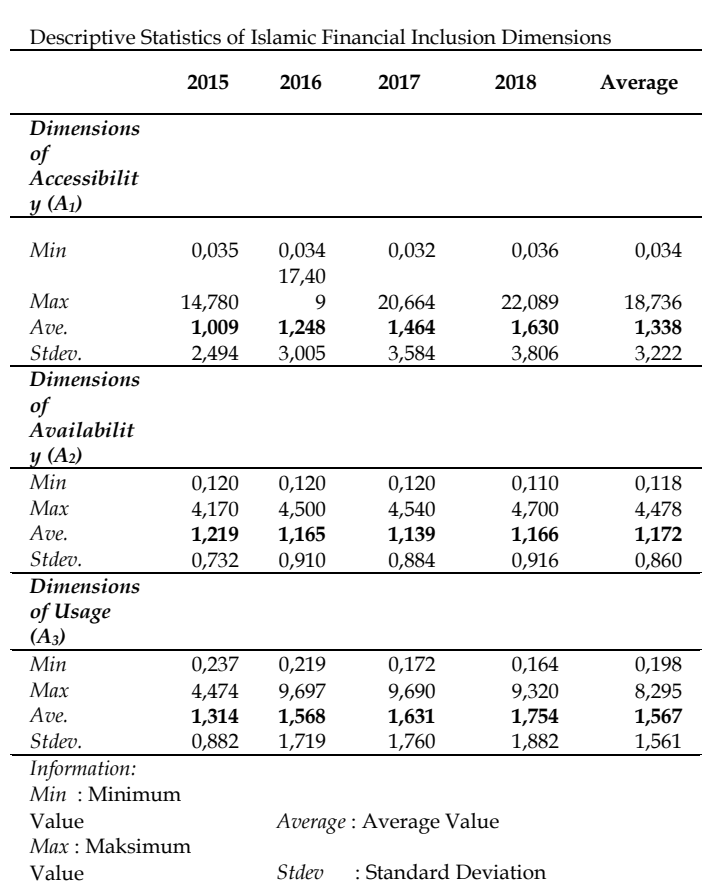

Source: Data processing results, 2019

An inclusive financial system must have as many users as possible, therefore an inclusive financial system must reach widely among users. The proportion of the population that has a bank account is a measure for banking penetration. One indicator that represents this measure is the number of Islamic Banking Third Party Funds (DPK) per 1000 adult population. This study uses the ratio of Islamic banking DPK consisting of Sharia Commercial Banks, Sharia Business Units and Sharia People Financing Banks per province to 1000 adult population during the 2015-2018 period. The average total number of Islamic banking deposits per 1000 adult population in Indonesia in the 2015-2018 period was around 1.338 
billion rupiah (see Table 4.1). Of the 33 provinces, DKI Jakarta Province has the highest number of Islamic banking deposits compared to other provinces, reaching an average of 18.736 billion rupiah per 1000 adult population.

In addition to banking penetration (accessibility), availability of banking services (availability) is also used to measure financial inclusion that illustrates the reach of the public in accessing banking financial services. The indicator of the availability of banking services is the number of outlets (be it offices, branch offices, ATMs, etc.). The availability of banking branches that can be reached by the public shows the spread of banking services. The more and more widespread the spread of banking branches, the higher the banking services provided. ${ }^{11}$ This study uses the number of sharia banking offices which include Sharia Commercial Banks and Sharia Business Units per province per 100,000 adult population to measure the availability dimension. In 20152018, the average number of sharia banking offices to serve every 100,000 population in Indonesia was 1.17 units or in other words there were 11 units available to serve 1 million residents (See Table 3.1). This amount is certainly a minimal amount related to the availability of Islamic banking services in the

\footnotetext{
${ }^{11}$ BintanBadriatulUmmahet al., AnalisisInklusiKeuangandanPemerataanPendap atan di Indonesia, JurnalEkonomidanKebijakanPembanguan, Vol 4 No 1, 2015, h. 16
} through Islamic Financial Inclusion region. Of the 33 provinces, DKI Jakarta in 2015 and Nanggroe Aceh Darussalam in 2016-2018 occupy the top position of the availability of sharia banking services compared to other provinces, reaching an average of 4.4 units per 100,000 population or 44 units per 1 million available adult population.

Access to charged financial services is not enough so this usage dimension indicator is also included in the measurement of an inclusive financial system. In this study, the usage indicator is seen from the proportion of the amount of Islamic banking financing to the GRDP value of each province during the 2015-2018 period. The calculation results show that the average total contribution of financing to GRDP per province is around 1.5 billion rupiah (See Table 3.1). DKI Jakarta Province has the highest average funding contribution to GRDP compared to other provinces, reaching an average of 8.29 billion rupiah.

\subsubsection{Islamic Financial Inclusion} Dimension Index

In calculating dimension index values, each dimension requires weight. Weights are determined based on how large these dimensions can affect financial inclusion. In addition to determining weights, calculating the index for each dimension of financial inclusion also requires the upper and lower limits of each indicator. ${ }^{12}$ The weights,

${ }^{12}$ BintanBadriatulUmmahet al.,
AnalisisInklusiKeuangandanPemeratanPendap
atan di Indonesia,


62 IQTISHODUNA: Jurnal Ekonomi Islam Volume 9 Issue1, April 2020

upper and lower limits used to calculate the index of the three dimensions of financial inclusion in this study are summarized in table 3.2 .

Table 3.2Sharia Financial Inclusion Dimension Index Calculation Data

\begin{tabular}{|c|c|c|c|c|c|c|}
\hline \multirow[t]{2}{*}{$\begin{array}{c}\text { Dimensio } \\
\mathrm{n} \\
(d i)\end{array}$} & \multirow{2}{*}{$\begin{array}{c}\text { W } \\
\text { hei } \\
\text { gt } \\
(W \\
i)\end{array}$} & \multirow{2}{*}{$\begin{array}{c}\text { Lowe } \\
r \\
\text { Limit } \\
\left(m_{i}\right)\end{array}$} & \multicolumn{4}{|c|}{$\begin{array}{l}\text { Upper Limit } \\
\left(M_{i}\right)\end{array}$} \\
\hline & & & 2015 & 2016 & 2017 & 2018 \\
\hline Banking & 1 & 0 & 14,78 & 17,4 & 20,66 & 22,0 \\
\hline $\begin{array}{l}\text { Penetratio } \\
\mathrm{n}\left(d_{1}\right)\end{array}$ & & & 0 & 09 & 4 & 89 \\
\hline $\begin{array}{l}\text { Availabili } \\
\text { ty of } \\
\text { Financial } \\
\text { Services }(d \\
\text { 2) }\end{array}$ & 0,5 & 0 & 4,170 & $\begin{array}{r}4,50 \\
0\end{array}$ & 4,540 & $\begin{array}{r}4,70 \\
0\end{array}$ \\
\hline Usage $\left(d_{3}\right)$ & 0,5 & 0 & 4,474 & $\begin{array}{r}9,69 \\
7 \\
\end{array}$ & 9,690 & $\begin{array}{r}9,32 \\
0 \\
\end{array}$ \\
\hline
\end{tabular}

Source: Data processing results, 2019

Determination of the maximum value and minimum value used is based on data from 33 provinces in Indonesia. The lower limit or minimum value (mi) of each dimension in this study is 0 .

Table 3.3Descriptive Statistics of Islamic Financial Inclusion Dimension Index

\begin{tabular}{|c|c|c|c|c|}
\hline \multicolumn{5}{|c|}{$\begin{array}{l}\text { Descriptive Statistics of Islamic Financial } \\
\text { Inclusion Dimension Index }\left(d_{i}\right)\end{array}$} \\
\hline & 2015 & 2016 & 2017 & 2018 \\
\hline \multicolumn{5}{|l|}{$\begin{array}{l}\text { Accessibili } \\
\text { ty Index } \\
\left(d_{1}\right) \\
\end{array}$} \\
\hline Min & 0,002 & 0,002 & 0,002 & 0,002 \\
\hline $\operatorname{Max}$ & 1,000 & 1,000 & 1,000 & 1,000 \\
\hline Ave. & 0,068 & 0,072 & 0,071 & 0,074 \\
\hline Stdev & 0,169 & 0,173 & 0,173 & 0,172 \\
\hline \multicolumn{5}{|l|}{$\begin{array}{l}\text { Availabilit } \\
\text { y Index }\left(d_{2}\right)\end{array}$} \\
\hline Min & 0,014 & 0,013 & 0,013 & 0,012 \\
\hline Max & 0,500 & 0,500 & 0,500 & 0,500 \\
\hline Ave. & 0,146 & 0,129 & 0,125 & 0,124 \\
\hline Stdev & 0,088 & 0,101 & 0,097 & 0,097 \\
\hline \multicolumn{5}{|l|}{$\begin{array}{l}\text { Usage } \\
\text { Indekx }\left(d_{3}\right)\end{array}$} \\
\hline Min & 0,026 & 0,011 & 0,009 & 0,009 \\
\hline $\operatorname{Max}$ & 0,500 & 0,500 & 0,500 & 0,500 \\
\hline
\end{tabular}

JurnalEkonomidanKebijakanPembanguan, Vol 4 No 1, 2015, h. 9

\begin{tabular}{lllll} 
Ave. & $\mathbf{0 , 1 4 7}$ & $\mathbf{0 , 0 8 1}$ & $\mathbf{0 , 0 8 4}$ & $\mathbf{0 , 0 9 4}$ \\
Stdev & 0,099 & 0,089 & 0,091 & 0,101 \\
\hline Information: & & & & \\
\hline Min & & & \\
:Minimum & & & \\
Value & Average : Average Value & \\
Max: & & \\
Maksimum & & \\
Value & Stdev & : Standard Deviation
\end{tabular}

Source: Data processing results, 2019

As shown in table 3.3, from 33 provinces in Indonesia, on average the achievement index of the accessibility dimension index increased during the period 20152018. From 0.068 in 2015 to 0.074 in 2018. Although the increase in the accessibility index value is not so significant, it shows that public access to Islamic financial services is getting better. Unlike the accessibility index value which increases every year, the availability and usage index values decrease during the study period.

From the proportion of the three dimensions that comprise the Islamic financial inclusion index in table 3.3 above, the availability index has the best average value over the period 2015-2018, followed by the dimensions of usage then accessibility. These results indicate that Islamic financial inclusion in Indonesia is mainly determined by the availability and usage dimensions. While the accessibility dimension has a relatively small proportion compared to the two even though it has always increased during the study period.

A higher availability index value than the accessibility index shows that with the availability of Islamic 
banking service offices in 33 provinces of Indonesia, people still experience limited access to reach financial services due to several obstacles experienced, namely low income levels, complicated bank operations, lack of financial education and banking, high bank administration fees and the distance of the bank from the place of residence. ${ }^{13}$ Most Indonesians work in the informal sector and have uncertain income. For formal institutions such as banks, fixed and certain income from customers is a guarantee for the continuity of their business, therefore people who have uncertain income are considered unbankable people, it is difficult to interact with formal financial institutions. ${ }^{14}$

Graph 3.1 Number of Sharia Bank Offices (BUS and UUS) for 2015-2018

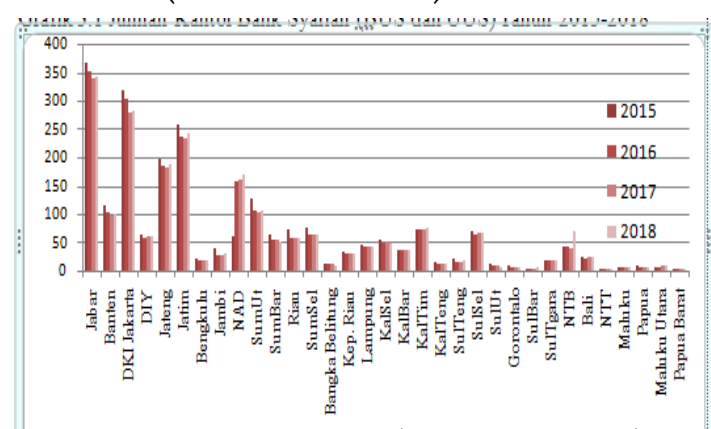

Source: OJK Sharia Banking Statistics, processed 2019

${ }^{13}$ Departemen Pengembangan Akses Keuangan dan UMKM Bank Indonesia, Booklet Keuangan Inklusif, 2014, h. 4 https://www.bi.go.id/id/perbankan/keua nganinklusif/edukasi/Pages/Booklet-

Keuangan-Inklusif.aspxaccessedJanuary 22, 2019

14 I Made Sanjaya, Inklusi Keuangan dan Pertumbuhan Inklusif Sebagai Strategi Pengentasan Kemiskinan di Indonesia, Tesis. Institut Pertanian Bogor, 2014, h. 33 through Islamic Financial Inclusion

Sharia bank service offices in 33 provinces of Indonesia have been established and are operating (See Graph 3.1). With the availability of sharia bank offices both Sharia Commercial Banks (BUS) and Sharia Business Units (UUS) that can be reached by the public shows the spread of financial services. The more and more widespread the locations of bank branch offices, the higher the range of financial services. Although sharia bank offices are available throughout Indonesia, the number of DPK that reflects account ownership of both savings and community deposits in sharia banking is still uneven (Graph 4.2). There was a very large difference between the number of Islamic banking deposits in DKI Jakarta province and 32 other provinces. DKI Jakarta's DPK has an average nominal over the 2015-2018 period of more than 130 trillion. Whereas in other provinces it only ranges between 100 billion-20 trillion.

Graph 3.2 Number of DPK Sharia Banking in 2015-2018

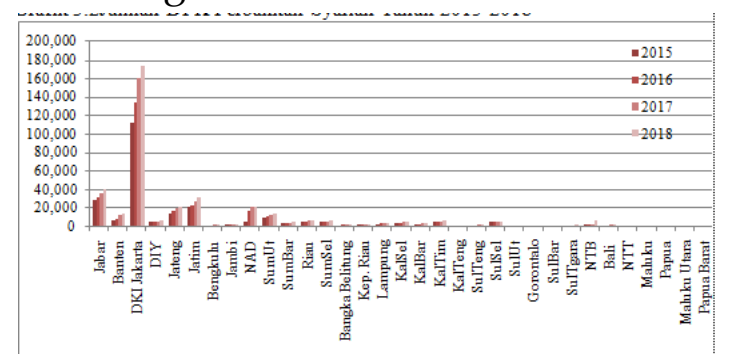

Source: OJK Sharia Banking Statistics, processed 2019

Graph 3.2 shows that public access to Islamic financial services assessed by the number of DPK in eastern Indonesia is still relatively lower than the provinces in the western region of Indonesia. Uneven 
64 IQTISHODUNA: Jurnal Ekonomi Islam Volume 9 Issue1, April 2020

Islamic banking deposits resulted in an average level of Islamic financial inclusion index from the dimensions of accessibility as measured by the ratio of the number of bank deposits in both Islamic Commercial Banks, Business Units and Islamic People's Financing Banks per 1,000 adult population is relatively low.

Graph 3.3 Number of Sharia Banking Financing in 2015-2018

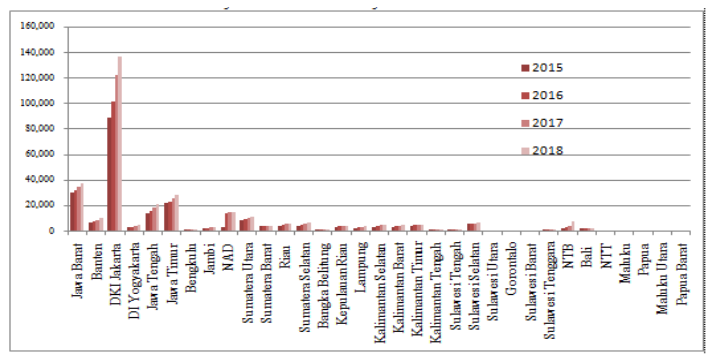

Source: OJK Sharia Banking Statistics, processed 2019

Similar to the low level of accessibility, this is due to various reasons such as the distance that is far enough to reach the nearest bank, the product offered is not appropriate to the needs, or has a bad experience with the service provider. ${ }^{15}$ In accordance with research conducted by the World Bank, only $17 \%$ of the total population of Indonesia borrowed from banks, and around one third borrowed from the informal sector. The main reason for not borrowing is due to incomplete documents indicating the unavailability of collateral as a second problem. Loans are not a top priority. The use of credit or financing is still highly concentrated in the informal sector

\footnotetext{
${ }^{15}$ BintanBadriatulUmmah, et al.,AnalisisInklusiKeuangandanPemerataanPend apatan di Indonesia, JurnalEkonomidanKebijakanPembanguan,Vol 4 No. 1 , h. 7
}

such as loans from employers, family, friends, and others. ${ }^{16}$

3.1.3 Islamic Financial Inclusion Index in 33 provinces in Indonesia

Islamic financial inclusion index can be seen from three dimensions of financial inclusion. How big is the index dimension of banking penetration, the availability of banking services, and the use of banking determines the index of financial inclusion. Graph 3.4 presents the value of Islamic Financial Inclusion Index (IIK) in 33 provinces in Indonesia. Put simply, provinces are divided into three categories in IIK measurement: provinces with low IIK for provinces that have an index value of less than 0.3 ; provinces with medium IIK values for provinces that have IIK values between 0.3 and 0.6 , and provinces with high IIK values for provinces that have IIK values between 0.6 and $1 .{ }^{17}$

\footnotetext{
16Bank Dunia, Meningkatkan Akses Terhadap Jasa Keuangan di Indonesia: Ringkasan Eksekutif, h. 2-3

http:/ / documents.worldbank.org/curated/ en/372831468039054109/pdf/520320WP0v1 0BA10Box345548B01PUBLIC1.pdfaccsessed Januari 22, 2019

${ }^{17}$ Mandira Sarma, Indexof Financial Inclusion - A measure of financial sector inclusiveness, Berlin Working Papers on Money, Finance, Trade and Development No. 07, 2012, h. 25
} 
Novatul Isrowiyah, Warno, Rahman El Junusi:

Development Strategy for Micro, Small and Medium Enterprises through Islamic Financial Inclusion

Graph 3.4 Sharia Financial Inclusion Ranking in 33 provinces in Indonesia in 2015-2018

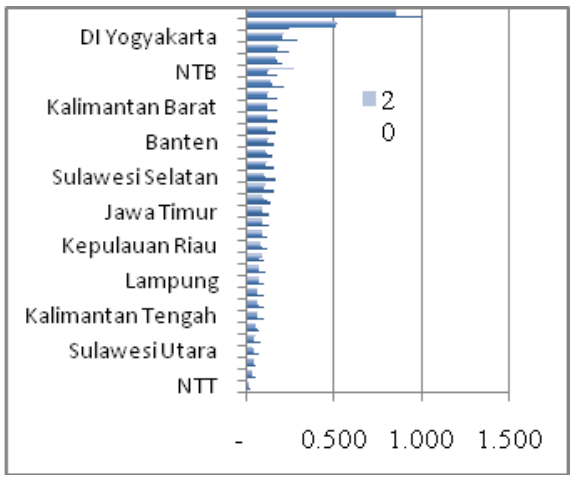

Source: Data processing results, 2019

Graph 3.4 shows the highest index value owned by DKI Jakarta province. in 2015, this province recorded a very high Islamic IIK value of 1 . As was the case in 2015 , in 2016-2018 the province of DKI Jakarta had the highest Islamic IIK value with a successive index value of $0.847 ; 0.847$ and 0.852 . While the lowest index is owned by the province of East Nusa Tenggara (NTT) during 2015-2018 with sharia IIK values respectively $0.022 ; 0.012$; 0.011 and 0.010 . Based on the value of Islamic financial inclusion index, the level of Islamic financial inclusiveness in Java is lower than in Kalimantan and Sumatra. When viewed from the number of deposits, bank offices and the amount of Islamic banking financing, the island of Jawarelatif is higher than Kalimantan and Sumatra, but the value of the Islamic financial inclusion index in Java is relatively lower, this is because the number of Islamic banking deposits representing the number of accounts, number of offices banks, and the amount of Islamic banking financing is not proportional to the total population in Java.

Table 3.5 Sharia Financial Inclusion Index in 33 Provinces in Indonesia

\begin{tabular}{|c|c|c|c|c|c|}
\hline Provinces & 2015 & 2016 & 2017 & 2018 & Average \\
\hline Jawa Barat & 0,176 & 0,116 & 0,112 & 0,112 & 0,129 \\
\hline Banten & 0,156 & 0,111 & 0,116 & 0,120 & 0,126 \\
\hline DKI Jakarta & 1,000 & 0,847 & 0,847 & 0,852 & 0,887 \\
\hline $\begin{array}{l}\text { DI } \\
\text { Yogyakarta } \\
\text { Jawa }\end{array}$ & 0,287 & 0,198 & 0,201 & 0,212 & 0,225 \\
\hline Tengah & 0,122 & 0,084 & 0,084 & 0,088 & 0,095 \\
\hline Jawa Timur & 0,128 & 0,086 & 0,086 & 0,088 & 0,097 \\
\hline Bengkulu & 0,176 & 0,119 & 0,115 & 0,120 & 0,133 \\
\hline Jambi & 0,156 & 0,097 & 0,096 & 0,103 & 0,113 \\
\hline NAD & 0,240 & 0,510 & 0,516 & 0,505 & 0,443 \\
\hline $\begin{array}{l}\text { Sumatera } \\
\text { Utara } \\
\text { Sumatera }\end{array}$ & 0,167 & 0,117 & 0,112 & 0,114 & 0,128 \\
\hline Barat & 0,209 & 0,142 & 0,134 & 0,129 & 0,154 \\
\hline Riau & 0,147 & 0,111 & 0,108 & 0,109 & 0,119 \\
\hline $\begin{array}{l}\text { Sumatera } \\
\text { Selatan } \\
\text { Bangka }\end{array}$ & 0,151 & 0,102 & 0,104 & 0,110 & 0,117 \\
\hline $\begin{array}{l}\text { Belitung } \\
\text { Kepulauan }\end{array}$ & 0,135 & 0,112 & 0,100 & 0,089 & 0,109 \\
\hline Riau & 0,115 & 0,086 & 0,081 & 0,079 & 0,090 \\
\hline Lampung & 0,097 & 0,068 & 0,067 & 0,068 & 0,075 \\
\hline $\begin{array}{l}\text { Kalimantan } \\
\text { Selatan } \\
\text { Kalimantan }\end{array}$ & 0,237 & 0,172 & 0,184 & 0,174 & 0,192 \\
\hline $\begin{array}{l}\text { Barat } \\
\text { Kalimantan }\end{array}$ & 0,173 & 0,119 & 0,116 & 0,118 & 0,132 \\
\hline $\begin{array}{l}\text { Timur } \\
\text { Kalimantan }\end{array}$ & 0,200 & 0,170 & 0,164 & 0,167 & 0,175 \\
\hline $\begin{array}{l}\text { Tengah } \\
\text { Sulawesi }\end{array}$ & 0,093 & 0,059 & 0,058 & 0,058 & 0,067 \\
\hline $\begin{array}{l}\text { Tengah } \\
\text { Sulawesi }\end{array}$ & 0,105 & 0,068 & 0,067 & 0,068 & 0,077 \\
\hline $\begin{array}{l}\text { Selatan } \\
\text { Sulawesi }\end{array}$ & 0,161 & 0,103 & 0,099 & 0,099 & 0,116 \\
\hline Utara & 0,064 & 0,036 & 0,035 & 0,031 & 0,042 \\
\hline Gorontalo & 0,098 & 0,064 & 0,053 & 0,056 & 0,068 \\
\hline $\begin{array}{l}\text { Sulawesi } \\
\text { Barat } \\
\text { Sulawesi }\end{array}$ & 0,079 & 0,039 & 0,040 & 0,047 & 0,051 \\
\hline Tenggara & 0,113 & 0,085 & 0,087 & 0,082 & 0,092 \\
\hline NTB & 0,176 & 0,118 & 0,128 & 0,269 & 0,173 \\
\hline Bali & 0,092 & 0,061 & 0,061 & 0,059 & 0,068 \\
\hline NTT & 0,022 & 0,012 & 0,011 & 0,010 & 0,014 \\
\hline Maluku & 0,046 & 0,038 & 0,037 & 0,037 & 0,040 \\
\hline $\begin{array}{l}\text { Papua } \\
\text { Maluku }\end{array}$ & 0,047 & 0,030 & 0,028 & 0,026 & 0,033 \\
\hline $\begin{array}{l}\text { Utara } \\
\text { Papua }\end{array}$ & 0,093 & 0,069 & 0,090 & 0,090 & 0,086 \\
\hline $\begin{array}{l}\text { Barat } \\
\text { Average }\end{array}$ & 0,065 & 0,056 & 0,051 & 0,048 & 0,055 \\
\hline total & 0,161 & 0,127 & 0,127 & 0,131 & 0,137 \\
\hline
\end{tabular}


IQTISHODUNA: Jurnal Ekonomi Islam

66 Volume 9 Issue1, April 2020

Source: Data processing results, 2019

The results of the calculation of Islamic financial inclusion index in 33 provinces in Indonesia show that DKI Jakarta Province is categorized as the province with the highest index, which has an average index value during the 2015-2018 research period of 0.887 . DKI Jakarta has the highest level of financial inclusion among other provinces because of the high three dimensions of financial inclusion. The province included in the current IIK is Nanggroe Aceh Darussalam (NAD) with an index of 0.443 . At first the province was in a low position, then in 2016 and 2017 it experienced an increase and entered into a moderate position. This is because the dimensions of availability (banking availability) and the dimensions of usage (use of banking services) Nanggroe Aceh Darussalam reached 0.5 or at a moderate position in 20162018.

When viewed from the distribution of the three dimensions of Islamic financial inclusion, DKI Jakarta province is much higher compared to other provinces. As a result, the level of financial inclusion in all provinces looks much worse. But if Jakarta is excluded from the calculation, the value of each province's financial inclusion index is too large. While 31 other provinces besides DKI Jakarta and NAD are classified as low level IIK.

The average value of the Islamic financial inclusion index achieved by Indonesia is 0.139 . This means that the level of Islamic financial inclusion in Indonesia is in the low category during the 2015-2018 period. The decline in the Islamic financial inclusion index in most provinces in Indonesia led to the low level of Islamic financial inclusion in Indonesia. In addition, there is only one province with an index value that is included in the high category in Indonesia, generally showing poor performance in terms of the inclusiveness of the Islamic financial sector during this period..

Graph 3.6 Development of Islamic Financial Inclusion Index for the Period of 2015-2018

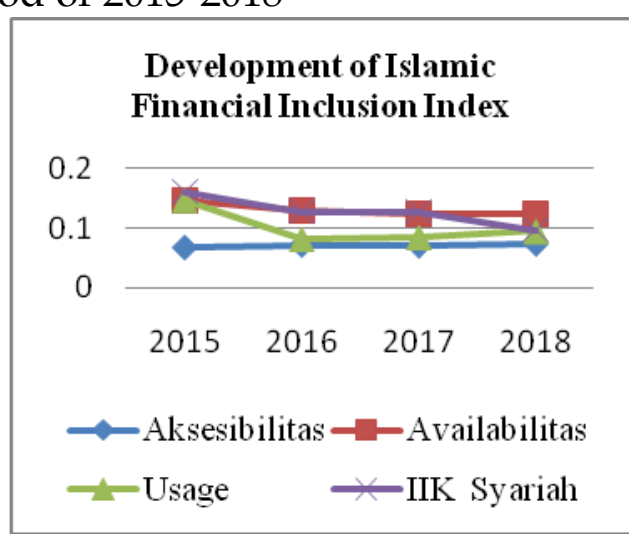

Source: Data processing results, 2019

As shown in Graph 3.5, the Islamic financial inclusion index in Indonesia has decreased from 2015 to 2018. In 2015 the Islamic financial inclusion index in Indonesia reached 0.161 and decreased to 0.131 in 2018 . This shows that there was a decrease in service inclusiveness Islamic finance in Indonesia for 4 years. Decrease in Islamic financial inclusion in Indonesia, due to a decrease in every dimension of financial inclusion except banking penetration (accessibility). 
Novatul Isrowiyah, Warno, Rahman El Junusi:

Development Strategy for Micro, Small and Medium Enterprises

3.2 Sharia Financing in the MSME Sector

Table 3.7 Proportion of Sharia Financing for MSME and NonMSME Sector to Total Sharia Banking Financing (Billion)

\begin{tabular}{|c|c|c|c|c|c|c|c|c|}
\hline \multirow[b]{2}{*}{ Pambiaygan } & \multicolumn{2}{|c|}{2015} & \multicolumn{2}{|c|}{2016} & \multicolumn{2}{|c|}{2017} & \multicolumn{2}{|c|}{2018} \\
\hline & Nominal & Persen & $\Lambda \beta_{\min }$ & Persen & Nominal & Persen & Nominal & Persen \\
\hline Seltor LMKM & 53.669 & $24,53 \%$ & 58.101 & $22,81 \%$ & 62.747 & $21,38 \%$ & 66.315 & $20,14 \%$ \\
\hline Seltor non UMKM & 165.092 & $75,47 \%$ & 196.568 & $77,19 \%$ & 230.711 & $78,62 \%$ & 262.962 & $79,86 \%$ \\
\hline Total Pambiayagn & 218.761 & $100 \%$ & 254.670 & $100 \%$ & 293.459 & $100 \%$ & 329.277 & $100 \%$ \\
\hline
\end{tabular}

Source: OJK Sharia Banking Statistics, processed 2019

Until December 2018, the proportion of distribution of sharia financing in the MSME sector to total sharia financing was 20.14 percent. This figure is only a quarter of the amount of Islamic finance disbursed to the economic sector. This is evidence that the financial services available cannot be utilized or utilized to the maximum by the existing MSMEs. Through the usage index in the preparation of the Islamic financial inclusion index in this study, obtained results that support this. The average index value of the use of financial services by the people in Indonesia during 2015-2018 was only 0.099 from a scale of 1.

Provinces with the highest nominal sharia financing in the 20152018 MSME sector were dominated by provinces in the Java island region (West Java, East Java, Central Java and including DKI Jakarta), only one outside of Java, namely North Sumatra. While the lowest nominal was dominated by Eastern Indonesia (North Maluku, NTT, through Islamic Financial Inclusion Gorontalo, West Papua, Maluku and North Sulawesi).

Graph 3.8 Sharia Financing in the 2015-2018 MSME sector

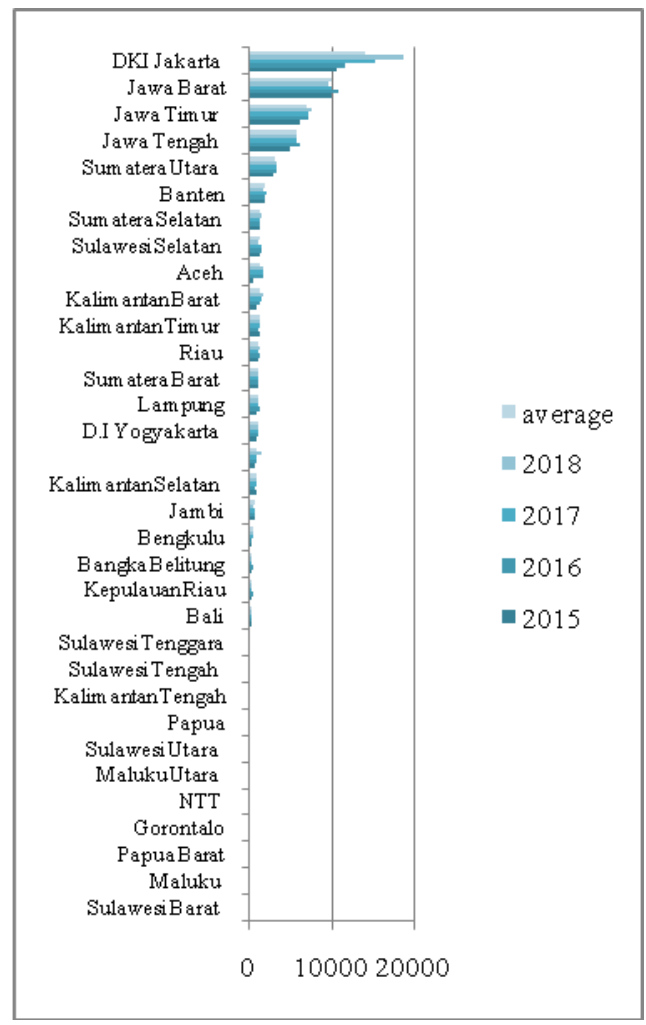

Source: OJK Sharia Banking Statistics, processed 2019

Although the highest nominal sharia financing is dominated by the island of Java, including DKI Jakarta, the highest growth of financing provided by the Islamic banking sector in the MSME sector was achieved by provinces outside of Java, Aceh, NTB and West Kalimantan with an average annual growth of 20-60\%. Even from 2015 to 2018 Aceh experienced a dramatic growth in Islamic financing with a growth value of nearly $200 \%$. See Table 3.8 
Table 3.9 Growth of Sharia Financing for the MSME Sector in 2015-2018 (billions of rupiah)

\begin{tabular}{|c|c|c|c|c|c|c|}
\hline Provinses & 2015 & 2016 & 2017 & 2018 & $\begin{array}{c}\text { Growth } \\
2015- \\
2018 \\
\end{array}$ & $\begin{array}{l}\text { Growth } \\
\text { Average } \\
\text { per Year }\end{array}$ \\
\hline Aceh & 595,5 & $1.728,47$ & $1.752,54$ & $1.726,83$ & $190,0 \%$ & $63,4 \%$ \\
\hline $\begin{array}{l}\text { Nusa } \\
\text { Tenggara }\end{array}$ & 792,8 & & & & & \\
\hline $\begin{array}{l}\text { Barat } \\
\text { Kalimantan } \\
\text { Barat }\end{array}$ & 927,57 & $1.468,67$ & $1.594,58$ & $1.781,99$ & $94,8 \%$ & $28,1 \%$ \\
\hline $\begin{array}{l}\text { DKI } \\
\text { Jakarta }\end{array}$ & $10.701,3$ & $11.752,3$ & $15.398,2$ & $18.744,2$ & $75,2 \%$ & $20,9 \%$ \\
\hline Bali & 310,06 & 371,44 & 482,2 & 463,71 & $49,6 \%$ & $15,3 \%$ \\
\hline $\begin{array}{l}\text { Bangka } \\
\text { Belitung }\end{array}$ & 390,07 & 590,15 & 411,74 & 466,16 & $19,5 \%$ & $11,4 \%$ \\
\hline $\begin{array}{l}\text { Kalimantan } \\
\text { Tengah }\end{array}$ & 217,92 & 233,99 & 233,62 & 268,93 & $23,4 \%$ & $7,4 \%$ \\
\hline $\begin{array}{l}\text { Jawa } \\
\text { Timur }\end{array}$ & $6.315,81$ & $7.191,42$ & $7.354,90$ & $7.683,86$ & $21,7 \%$ & $6,9 \%$ \\
\hline Lampung & $1.068,08$ & $1.406,73$ & $1.271,56$ & $1.237,06$ & $15,8 \%$ & $6,5 \%$ \\
\hline $\begin{array}{l}\text { Sumatera } \\
\text { Selatan }\end{array}$ & $1.390,62$ & $1.406,34$ & $1.494,15$ & $1.639,88$ & $17,9 \%$ & $5,7 \%$ \\
\hline $\begin{array}{l}\text { Jawa } \\
\text { Tengah }\end{array}$ & $5.105,61$ & $6.250,89$ & $5.920,69$ & $5.872,21$ & $15,0 \%$ & $5,4 \%$ \\
\hline $\begin{array}{l}\text { Kalimantan } \\
\text { Timur }\end{array}$ & $1.370,14$ & $1.131,95$ & $1.343,17$ & $1.477,38$ & $7,8 \%$ & $3,8 \%$ \\
\hline $\begin{array}{l}\text { Sumatera } \\
\text { Utara }\end{array}$ & $3.088,29$ & $3.392,24$ & $3.397,70$ & $3.405,68$ & $10,3 \%$ & $3,4 \%$ \\
\hline $\begin{array}{l}\text { D.I } \\
\text { Yogyakarta }\end{array}$ & $1.110,47$ & $1.282,02$ & $1.148,30$ & $1.188,57$ & $7,0 \%$ & $2,8 \%$ \\
\hline $\begin{array}{l}\text { Maluku } \\
\text { Utara }\end{array}$ & 69,75 & 82,37 & 68,28 & 72,71 & $4,2 \%$ & $2,5 \%$ \\
\hline Bengkulu & 480,59 & 502,25 & 525,14 & 514,08 & $7,0 \%$ & $2,3 \%$ \\
\hline Riau & $1.251,43$ & $1.313,87$ & $1.291,37$ & $1.315,63$ & $5,1 \%$ & $1,7 \%$ \\
\hline $\begin{array}{l}\text { Sulawesi } \\
\text { Tenggara }\end{array}$ & 265,48 & 268,68 & 266,46 & 273,62 & $3,1 \%$ & $1,0 \%$ \\
\hline $\begin{array}{l}\text { Kalimantan } \\
\text { Selatan }\end{array}$ & 914,34 & 99,81 & $1.027,10$ & 919,55 & $0,6 \%$ & $0,7 \%$ \\
\hline $\begin{array}{l}\text { Sumatera } \\
\text { Barat }\end{array}$ & $1.284,15$ & $1.292,38$ & $1.303,58$ & $1.286,13$ & $0,2 \%$ & $0,1 \%$ \\
\hline Jawa Barat & $10.157,3$ & $10.859,1$ & $10.062,3$ & $9.708,49$ & $-4,4 \%$ & $-1,3 \%$ \\
\hline Banten & $2.093,28$ & $2.121,18$ & 2.129,62 & $1.858,55$ & $-11,2 \%$ & $-3,7 \%$ \\
\hline $\begin{array}{l}\text { Sulawesi } \\
\text { Selatan }\end{array}$ & $1.461,12$ & $1.574,55$ & $1.541,37$ & $1.258,10$ & $-13,9 \%$ & $-4,2 \%$ \\
\hline $\begin{array}{l}\text { Kepula } \\
\text { Riau }\end{array}$ & 423,7 & 512,14 & 381,69 & 335,15 & $-20,9 \%$ & $-5,6 \%$ \\
\hline NTT & 73,02 & 65,49 & 54,83 & 59,04 & $-19,1 \%$ & $-6,3 \%$ \\
\hline $\begin{array}{l}\text { Sulawesi } \\
\text { Tengah }\end{array}$ & 276,44 & 273,14 & 232,08 & 220,45 & $-20,3 \%$ & $-7,1 \%$ \\
\hline Papua & 179,11 & 165,68 & 155,17 & 137,52 & $-23,2 \%$ & $-8,4 \%$ \\
\hline Jambi & 847,27 & 819,66 & 715,37 & 643,75 & $-24,0 \%$ & $-8,7 \%$ \\
\hline $\begin{array}{l}\text { Sulawesi } \\
\text { Barat }\end{array}$ & 20,75 & 14,57 & 16,91 & 14,21 & $-31,5 \%$ & $-9,9 \%$ \\
\hline $\begin{array}{l}\text { Sulawesi } \\
\text { Utara }\end{array}$ & 173,93 & 142,79 & 130,55 & 114,5 & $-34,2 \%$ & $-12,9 \%$ \\
\hline $\begin{array}{l}\text { Papua } \\
\text { Barat }\end{array}$ & 63,77 & 73,51 & 53,27 & 33,62 & $-47,3 \%$ & $-16,4 \%$ \\
\hline Maluku & 30,95 & 25,32 & 14,92 & 14,31 & $-53,8 \%$ & $-21,1 \%$ \\
\hline Gorontalo & 74,6 & 64,79 & 49,85 & 35,28 & $-52,8 \%$ & $-21,8 \%$ \\
\hline
\end{tabular}

Source: OJK Sharia Banking Statistics, processed 2019

In most provinces in Indonesia, financing channeled by Islamic banks in the MSME sector is growing every year. It appears that the attention of banks, especially Islamic banking financing towards MSMEs in Indonesia is getting higher. Thus, the seriousness of Islamic banking financing to help support the improvement of MSME performance in several provinces has shown quite significant results. West Java Province has a large amount of Islamic finance in the MSME sector. However, it does not experience development every year because the nominal financing of the MSME sector always decreases. The provinces of West Papua, Maluku and Gorontalo became provinces that experienced a decrease in the nominal amount of financing in the MSME sector with an average annual decline of $21.8 \%$. The presence of Islamic banking should have a large impact on the growth of the real sector, especially encouraging the growth of the real sector in the micro, small and medium enterprises (MSMEs) sector which currently has a very important position in the national economy because of its contribution in employment and gross domestic income (GDP) ), as well as their flexibility and resilience in dealing with the economic crisis. ${ }^{18}$

3.3 The Effect of Islamic Financial Inclusion Index on Sharia Financing in the MSME Sector

\subsubsection{Simple Linear Regression Analysis}

${ }^{18}$ Muslimin Kara, Konstribusi Pembiayaan Perbankan Syariah terhadap Pengembangan Usaha Mikro, Kecil, dan Menengah, Jurnal Ahkam:Vol. XIII, No. 2, Juli 2013, h. 315-322 
Tabel 3.6 Simple Linear Regression Analysis Results

\begin{tabular}{|c|c|c|c|c|c|}
\hline \multicolumn{6}{|c|}{ Coefficients $^{a}$} \\
\hline \multirow[b]{2}{*}{ Model } & \multicolumn{2}{|c|}{$\begin{array}{c}\text { Unstandardiz } \\
\text { ed } \\
\text { Coefficients }\end{array}$} & $\begin{array}{c}\text { Standardi } \\
\text { zed } \\
\text { Coefficie } \\
\text { nts }\end{array}$ & & \\
\hline & B & $\begin{array}{l}\text { Std. } \\
\text { Error }\end{array}$ & Beta & $\mathrm{t}$ & Sig. \\
\hline 1 (Constant) & 4,273 & 151 & & $\begin{array}{r}28,3 \\
11\end{array}$ & ,000 \\
\hline IIK_Syariah & 1,499 & 143 & 677, & $\begin{array}{r}10,4 \\
96\end{array}$ & ,000 \\
\hline
\end{tabular}

a. Dependent Variable: Finan_MSME

Source: SPSS Output, 2019

Judging from the output values above, the sharia financial inclusion index is positive so it can be concluded that sharia financial inclusion has a positive and significant effect on sharia financing channeled to the MSME sector.

Table $\quad 3.7 \quad$ Coefficient of Determination

\begin{tabular}{l|c|r|r|r}
\multicolumn{5}{c|}{ Model Summary } \\
\hline \multirow{2}{*}{$\begin{array}{l}\text { Mode } \\
1\end{array}$} & $\mathrm{R}$ & $\begin{array}{c}\mathrm{R} \\
\text { Square }\end{array}$ & $\begin{array}{c}\text { Adjust } \\
\text { ed R } \\
\text { Square }\end{array}$ & $\begin{array}{c}\text { Std. Error } \\
\text { of the } \\
\text { Estimate }\end{array}$ \\
\hline 1 &, $677 \mathrm{a}$ &, 459 &, 455 &, 54013 \\
\hline
\end{tabular}

a. Predictors: (Constant), IIK_Sharia

b. Dependent Variable: Finan_MSME

Source: SPSS Output, 2019

The coefficient of determination ( $R$ Square) in the above calculation is 0.459 or equal to $45.9 \%$. This figure means that $45.9 \%$ of Islamic financing in the MSME sector can be explained using the Islamic financial inclusion index. in other words, the magnitude of the effect of the Islamic financial inclusion index on Islamic through Islamic Financial Inclusion financing channeled to the MSME sector is $45.9 \%$ while the remaining $54.1 \%$ is explained by other factors outside this regression model. Other factors affecting Islamic finance in the MSME sector can be explained by third party funds, Capital Adequacy Ratio, Non Performing Financing, BOPO, Financing Deposit Ratio, Equivalent Rate of Third Party Funds (ERDPK) and Bank Indonesia Sharia Certificate Bonuses (BSBIS). ${ }^{19}$ Sharia financing channeled by sharia banks in the MSME sector in Indonesia is also influenced by third party funds and liquidity. ${ }^{20 M S M E ~ N P L ~ i s ~ a l s o ~ o n e ~ o f ~}$ the factors that influence the supply of bank credit to MSMEs (Nurhidayat, 2010).

Based on data from 2015-2018, the results of the regression analysis using the SPSS statistical test indicate that the independent variable, the Islamic financial inclusion index compiled by the dimensions of access, availability and usage, affects sharia financing channeled to the Micro, Small and Medium Enterprises sector in Indonesia. When the Islamic financial inclusion index rises, the Islamic financing channeled to the MSME sector in

${ }^{19}$ Tamara Yuanita Muji Mardani, Analisis Fakor-Faktor Yang Memengaruhi Pembiayaan Bank Umum Syariah Untuk Sektor UMKM di Indonesia, Skripsi. Fakultas Ekonomi Institut Pertanian Bogor, 2016.

20Risna Destiana, AnalisisFaktorFaktor Internal yangMempengaruhiPembiayaan Usaha Mikro Kecil dan Menengah (UMKM) Pada Bank SyariahdiIndonesia, JurnalRisetKeuangandan Akuntansi,Vol. 2 Isue 1, Februari 2016, h. 15 - 28 
70 IQTISHODUNA: Jurnal Ekonomi Islam Volume 9 Issue1, April 2020

Indonesia tends to increase. In other words, provinces that have a high Islamic financial inclusion index, channeling Islamic financing to the MSME sector tend to be higher.

The high Islamic financial inclusion index was achieved due to the high amount of third party funds collected, the availability of bank office services in each region, and the large proportion of funding to provincial pdrb affecting the increasing amount of Islamic financing channeled to the MSME sector. In accordance with research conducted by Fahmy et al. . The study uses LDR and NPL control variables which show that LDR together with access variables and banking service use variables have a significant positive effect. Whereas the NPL has a negative but not significant direction.

Supported by Aldila and Puspitasari's research, third-party funds have a positive and significant effect on MSME lending at commercial banks in Indonesia. ${ }^{21}$ In addition to third party funds, the availability of sharia bank service offices can be utilized by MSMEs for access to capital, saving funds and transaction facilities. The development of loans extended to the MSME sector is inseparable from

\footnotetext{
${ }^{21}$ Gaby Firdha Aldila, Analisis Pengaruh Dana Pihak Ketiga, Tingkat Suku Bunga, dan Non Performing Loan Terhadap Penyaluran Kredit UMKM Pada Bank Umum di Indonesia, Jurnal Ekonomi Pembangunan, Vol 10 No. 1 Juni 2012, h. 81-88

Maya Puspitasari, Determinan Penyaluran Kredit Usaha Mikro, Kecil, dan Menengah (UMKM) Pada Bank Umum Konvensional di Indonesia, Jurnal Manajemen Bisnis Indonesia Edisi 2, 2018, h. 195-206
}

the ease of MSMEs to access Islamic financial services with the availability of Islamic bank service offices. The ease of access arises mainly because of two things, namely firstly because of the existence of office networks and services around MSMEs and secondly because of the ease (policy) obtaining capital from banks. ${ }^{22}$ Therefore financial inclusion needs to be increased to facilitate MSME access to Islamic financing. All parties must play a role in this matter, both the government, Islamic banks, and MSMEs themselves. Islamic banks are expected to be able to further expand access and socialize their strengths well so that Islamic banks can be a reinforcement and a companion to the development of MSMEs. While the government can provide training facilities for SMEs and create policies that are able to encourage the MSME sector in Indonesia through inclusive financial policies.

The results of the study show that financial inclusion and MSME growth have increased linearly so that a breakthrough needs to be sought to improve it, there have been many ways taken by the government, but until now the position of sharia banking is still at $5 \%$ and has not been able to go up in the last few years even though the number of Muslims in the The majority of Indonesia, the way that

${ }^{22}$ Obaid M Fahmy, et al.,
PengaruhKeuanganInklusifterhadapkredit yang
disalurkanpadasektor Usaha Mikro, Kecil dan
Menengah (UMKM) di Indonesia. Jurnal
Ekonomi Bisnis dan Kewirausahaan,Vol. 5,
No. 2, 2016, h. 131-132


can be done is to raise awareness of using Islamic banking in the transaction, so far the ongoing awareness process is still sporadic not comprehensive.

As shown in Graph 3.5, there has been a decline in the inclusiveness of Islamic financial services in Indonesia for 4 years. The decline in Islamic financial inclusion in Indonesia, due to a decline in every dimension of financial inclusion except banking penetration (accessibility), although the highest nominal amount of Islamic financing is dominated by Java islands including DKI Jakarta, the highest growth of financing channeled by Islamic banks in the MSME sector is achieved by outside provinces Java namely Aceh, NTB and West Kalimantan with an average annual growth of 20-60\%. Even from 2015 to 2018 Aceh experienced a dramatic growth in Islamic financing with a growth value of nearly $200 \%$. See Table 3.6.

In general, financial inclusion is linearly in line with the growth of financing from MSMEs by Islamic banking, but some are not all the same because judging from the data of DKI Jakarta is the most inclusive, but it turns out that Aceh shows a large growth and the percentage exceeds that in DKI, there is one interesting thing there namely the level of awareness of Muslims is greater than other regions.

The process of enhancing financial inclusion comprehensively by means of all parties working hand in hand, an example that is currently being done is the government gathering ulama and providing material related to Islamic banking and forbidden banking interest laws so that they are asked to switch to the sacrifice of sharia, but in practice Islamic community organizations such as Nahdlotul Ulama, Muhammadiyah, LDII, Persis, and other ways they are not seriously responding to be seen in doctrining or giving sermons to their pilgrims not continuously and without evaluating whether the pilgrims have switched sharia sacrifices or still remain in conventional banks, but for example related worshipers whose prayers have not been good then the cleric will monitor and evaluate through various ways so that the prayer turns out to be good.

Another example of the seriousness of the ulama in the process of increasing the financial inclusiveness of Islamic banking is that there are still differences in their views regarding the law of bank interest. in the end they conveniently said they chose the same Islamic and conventional banks.

Certain Islamic community organizations even have something strange in responding to banking, whether conventional or Islamic banking, that is, they forbid using services from banking, it needs to be examined specifically why the organization prohibits, but what needs to be noted is that it requires initial awareness from religious leaders before switching to the general public, it takes equal perception and law so that later it will be easier for them to indoctrinate. 
72 IQTISHODUNA: Jurnal Ekonomi Islam Volume 9 Issue1, April 2020

Voluntary disclosure of intellectual capital imposes challenges for firms operating in knowledge-intensive industries or environments. If an organization does not disclose intangible assets, there are several negative consequences. ${ }^{23}$

\section{Conclusion}

1. The results of the study indicate that the level of Islamic financial inclusion in Indonesia falls into the low category with an average value of IIK Sharia in Indonesia during the 2015-2018 period only 0.139 . DKI Jakarta has the highest level of Islamic financial inclusion among other provinces with an average index value of 0.887 . Whereas NAD is included in the medium inclusive level with an average index of 0.443 during the study period. While 31 other provinces besides DKI Jakarta and NAD are classified as low Islamic financial inclusion levels. There is only one province with an index value that is included in the high category in Indonesia, generally showing poor performance in terms of the inclusiveness of the Islamic financial sector during the study period.

2. The results of the quantitative analysis of this study also found

\footnotetext{
${ }^{23}$ Risnaeni, Umi Suswati. 2015. Intellectual

Capital : Toward The Development of Conceptual Framework For Its Standardized Reporting. Iqtishoduna: Jurnal Ekonomi Islam, 4(April), 1-16. Retrieved from http:/ / ejournal.iaisyarifuddin.ac.id/in dex.php/iqtishoduna/article/view/22
}

that Islamic financial inclusion had a positive and significant effect on Islamic financing channeled to the Micro, Small and Medium Enterprises sector in Indonesia. That is, when the Islamic financial inclusion index measured from three dimensions (accessibility, availability and availability) rises, then Islamic financing channeled to the MSME sector tends to increase.

3. MSMEs will be able to be increased with sufficient funding through mediation from banks, but there needs to be awareness and comprehensive ways to improve financial inclusion, one of which is the seriousness of religious leaders in delivering and doctrining their sermons regarding the use of Islamic banking, one of the regions that appears to be developing more rapid compared to other regions is Aceh.

\section{REFERENCES}

[BI] Bank Dunia, Meningkatkan Akses Terhadap Jasa Keuangan di Indonesia: Ringkasan Eksekutif diunduh darihttp://documents.worldb ank.org

[BI] Bank Indonesia, https://www.bi.go.id/id/um $\mathrm{km} /$ kredit/data/Pages/DataKredit-UMKM-Desember2018.aspx

[BI] Bank Indonesia, Indeks Keuangan Inklusifwww.bi.go.id

[BI] Bank Indonesia. 2014. Booklet Keuangan Inklusif tersedia padahttps://www.bi.go.id/id/ perbankan/keuanganinklusif/ed 
Development Strategy for Micro, Small and Medium Enterprises

ukasi/Pages/Booklet-KeuanganInklusif.aspx

[OJK] Otoritas Jasa Keuangan, "Survei Nasional Literasi dan Inklusi Keuangan 2016www.ojk.go.id

[OJK] Otoritas Jasa Keuangan, Statistik Perbankan Desember 2018 tersedia padawww.ojk.go.id

Aldila, Gaby Firdha. 2012. Analisis Pengaruh Dana Pihak Ketiga, Tingkat Suku Bunga, dan Non Performing Loan Terhadap Penyaluran Kredit UMKM Pada Bank Umum di Indonesia, Jurnal Ekonomi Pembangunan, Vol 10 No. $1,81-88$

Bank Dunia, Meningkatkan Akses Terhadap Jasa Keuangan di Indonesia: Ringkasan Eksekutif, tersedia

padahttp://documents.world bank.org

Basuki dan Prawoto. 2016. Analisis Regresi dalam Penelitian Ekonomi \& Bisnis: dilengkapi Aplikasi SPSS \& Eviews, Jakarta: Rajawali Pers

Destiana, Risna. 2016. Analisis FaktorFaktor Internal yang Mempengaruhi Pembiayaan Usaha Mikro Kecil dan Menengah (UMKM) Pada Bank Syariah di Indonesia, Jurnal Riset Keuangan dan Akuntansi,Vol. 2 Isue 1, 15 28

Fahmy, et al. 2016. Pengaruh Keuangan Inklusif terhadap kredit yang disalurkan pada sektor Usaha Mikro, Kecil dan Menengah (UMKM)di Indonesia, Jurnal Ekonomi Bisnis through Islamic Financial Inclusion

Kewirausahaan,Vol. 5, No. $2,118-135$

Gabriell, L.G \& Goeltom, M.S. Pengaruh pembangunan Keuangan Perbankan dan Akses Keuangan Perbankan Terhadap Kemiskinan di Indonesia. FE Universitas Indonesia, 2013.

Kara, Muslimin. 2013. Konstribusi Pembiayaan Perbankan Syariah Terhadap Pengembangan Usaha Mikro, Kecil, dan Menengah, Jurnal Ahkam: Vol. XIII, No. 2, 315322

Kementrian Koperasi dan Usaha Kecil dan Menengah Republik Indonesia, www.depkop.go.id Mardani, Tamara Yuanita Muji. 2016. Analisis Fakor-Faktor Yang Memengaruhi Pembiayaan Bank Umum Syariah Untuk Sektor UMKM di Indonesia, [Skripsi]. Fakultas Ekonomi Institut Pertanian Bogor

Nisa, et al. 2018. Implementasi Metode Pengukuran Indeks Keuangan Inklusif pada Sepuluh Bank Terbesar di Indonesia, Jurnal Inspirasi Bisnis dan Manajemen. Vol. 2 No. 2

Puspitasari,Maya. 2018. Determinan Penyaluran Kredit Usaha Mikro, Kecil, dan Menengah (UMKM) Pada Bank Umum Konvensional di Indonesia, Jurnal Manajemen Bisnis Indonesia Edisi 2, 195206

Rifa'i,Achmad. 2017.Peran Bank Pembiayaan Rakyat Syariah dalam Mengimplementasikan Keuangan Inklusif Melalui Pembiayaan UMKM, Jurnal Human Falah, Vol. 4. No. 2 
74 IQTISHODUNA: Jurnal Ekonomi Islam Volume 9 Issue1, April 2020

Risnaeni, Umi Suswati. 2015. Intellectual Capital : Toward The Development of Conceptual Framework For Its Standardized

Reporting. Iqtishoduna: Jurnal Ekonomi Islam, 4(April), 1-16. Retrieved

from http:/ / ejournal.iaisyarif uddin.ac.id/index.php/iqtish oduna/article/view/22

Sanjaya, I Made. 2014. Inklusi Keuangan dan Pertumbuhan Inklusif Sebagai Strategi Pengentasan Kemiskinan di Indonesia, Tesis. Institut Pertanian Bogor

Sarma, M and Pais, J. 2011.Financial Inclusion and Development: a Cross Country Analysis Journal of International Development, 23, 613-625.

Sarma, Mandira . 2012. Index of Financial Inclusion - A Measure of Financial Sector Inclusiveness, Berlin Working Papers on Money, Finance, Trade and Development No. 07

Sugiyono. 2018. Metode Penelitian Kuantitatif, Kualitatif dan RED, Bandung: Alfabeta Cet. Ke 8

Suharsono, Yudi. Keuangan Inklusif dan Keuangan Syariah Bisa Bersinergi, http://mysharing.co

Supriyanto. 2006. Pemberdayaan Usaha Mikro, Kecil, dan Menengah (UMKM) Sebagai Salah Satu Upaya Penanggulangan Kemiskinan, Jurnal Ekonomi \& Pendidikan, Volume 3 Nomor 1
Umar,Azwar Iskandar. 2017. Index of Syariah Financial Inclusionin Indonesia, Buletin Ekonomi 